\title{
Common Economic Space as Progressive Legal Institute of Integration in World Economy
}

\author{
Alibayeva Gulnar Aytzhanovna ${ }^{1}$, Zhumagulov Marat Imangalievich ${ }^{2} \&$ Kussainova Larisa Islyamovna $^{3}$ \\ ${ }^{1}$ Humanitarian University of Transport and Law Behalf D.A. Kunaev, Almaty, Kazakhstan \\ ${ }^{2}$ Academy of Public Administration under the President of the Republic of Kazakhstan, Astana, Kazakhstan \\ ${ }^{3}$ Joint Stock Company "Freedom Finance", Almaty, Kazakhstan \\ Correspondence: Alibayeva Gulnar Aytzhanovna, Humanitarian University of Transport and Law Behalf D.A. \\ Kunaev, 050022, Almaty, Kurmangazy Street, 107, Kazakhstan. Tel: 7-701-435-6089 E-mail: \\ alibayeva@yandex.ru
}

Received: July 7, 2015 Accepted: August 19, 2015 Online Published: November 29, 2015

doi:10.5539/jsd.v8n9p265 URL: http://dx.doi.org/10.5539/jsd.v8n9p265

\begin{abstract}
One of the most important manifestations of world economic system's globalization is its movement to the integration, which is showing, including, in creation of economic integration associations. This tendency is typical and for the Post-Soviet states. In this regard the period of the 1990th became especially active when in the territory of the former USSR there was the number of economic blocks - the Commonwealth of Independent States (CIS), the Union State of Belarus and Russia, the Common Economic Space (CES), the Organization of Central Asian cooperation (OTsAS), the Eurasian economic community (EurAsEC). The concept of the Common Economic Space (CES) was a consequence of searches most general and progressive legal institute in intensive integration processes in world economy. As a whole, formation of CES carries out in difficult economic and political situation. It demands the careful scientific analysis of all accompanying aspects.
\end{abstract}

Keywords: common economic space, integration processes, Customs union, national right, legal bases of common economic space, international treaty

\section{Introduction}

Today there are a lot of examples, when traditional contractual forms of cooperation between the states, the economic organizations and legal entities of various states successfully work. But the same subjects, especially in the conditions of an aggravation of power and financial problems, pay attention to advantages of their joint institutional decision. Even traditionally independent Japan starts being oriented to regional integration within South East Asia. In the European Union in August, 2011 the idea of creation of the European economic government, as reaction to events in Greece, Italy and Spain was discussed even.

Integration process on the former Post-Soviet space carries out rather difficult. It is explained, first of all, by that these or those integration configurations are formed under the influence of a many-sided complex of multidirectional factors (integration and not integration). At working out of effective concepts and strategies of integration associations' development it is necessary to consider all complex of factors. However in practice it appears, that it is rather difficult to make it, because the factors representing the phenomena of political and social reality, are extremely changeable.

Tendencies to creation of CES are observed in some other regions of the world. And though still there is no conventional approach to CES definition, the corresponding concept is enshrined in a number of important international legal documents. The sovereignty of the states passes test in this process, which undergoes high-quality transformation in a case to transfer by the state of part of the sovereign functions to supranational body.

The purpose of the real work in, that on the basis of the analysis of law rules, progressive forms of economic cooperation and integration of the states, new concepts and programs in this field, to present justification of features of formation and action of such new institute as the Common economic space.

The most part of the works included in the bibliography on this subject, represents the practical researches which to 
some extent are crossing with the subject of scientific article. The significant contribution to development of the concept of integration of the Post-Soviet states was made by scientists of CIS countries: R. G., Abdullo (2010), N. K., Isingarin (1998) P. C., Mirzayev (2004), B. O., Parakhonsky (2008), N. N., Shumsky (2012), etc.

The subject of cooperation of China, Russia and the Central Asian states in Central Asia is actively developed by the Chinese scientist Huasheng Zhao (2005).

The western experts also show a great interest to a studied problem. However this interest is rather specific, because the western researchers aren't engaged in forecasting of integration processes' development on Post-Soviet space, and put forward own concepts of involvement of CIS countries in world economic system. Works of known scientists testify to it Z., Bzhezinsky (1999), A., Cohen and S., Blank (2011), M., Olkott (2013), F., Starr (2008), J., Stiglitz (2005), etc.

\section{Scientific Methods}

The aim of the research has been achieved by means of general scientific and specialscientific methods: historical, structural-functional and formal-legal methods.

Conducting a research of the integration processes in the post-Soviet countries is impossible without reference to the historical origins of these phenomena, which determines the use of the historical method that, in turn, includes such research methods as: retrospection; historical comparison; historical analogy; historical periodization.

Consideration of the integration processes in their development stipulates utilization of structural-functional approach that examines an object as a system with its specific integrative properties and allows seeing the institutions and functions of integration associations. Such analysis enables us to discover the most important elements of the phenomena under consideration, and trace their interdependence and interconditionality.

A formal-legal method, applied as the main instrument in the study of the existing legal norms, permitted to carry out the analysis, systematization and classification of the legal regulations governing the Eurasian Economic Space.

Also, there had been used the elements of the dialectical approach that implies consideration of the subject in its development, in particular, there had been analyzed the evolution of integration processes in the post-Soviet space since their launch to the present day.

Moreover, the theoretical issues of the research had been studied taking into account the international experience in the integration processes in the world community.

\section{Results and Discussion}

Results of positive experience of the CIS activity, allow to its participants to note, that the states of the Commonwealth can interact in economic area by differently-level integration. For this purpose a raw of CIS countries began to create economic communities in narrow structure. For example, five states - participants of the CIS - Belarus, Kazakhstan, Kyrgyzstan, the Russian Federation and Tajikistan - since 1995 started forming the Customs Union (CU). For this purpose they concluded a large number of agreements. Among them is key the Contract on the Customs union and the Common Economic Space (CES) of February 26, 1999 (Agreement on the Customs union and the Common Economic Space, 1999), in which integration stages were defined.

At the first stage - to provide realization in full volume of free trade regime, in particular non-use of tariff and quantitative restrictions in mutual trade, introduction of uniform system of indirect taxes' collection, elimination of the administrative, fiscal and other obstacles complicating free movement of goods.

At the second stage - to create the Customs union assuming the uniform customs territory, the common customs tariff, cancellation of customs control on internal borders, unification of mechanisms of economy and trade regulation.

At the third stage - to create the common economic space providing carrying out the general economic policy and formation of a common services market, labor and capital, standardization of the national legislation, carrying out the coordinated social and scientifically-technological policy.

Presidents of Kazakhstan, Russia, Belarus and Ukraine declared on February 23, 2003 intention to create the Common economic space - the project of economic and political integration. And on September 19, 2003 - at the summit in Yalta the Agreement on CES formation is signed (Agreement on Common economic space formation, 2003).

The agreement provided development of the Complex of the main measures for CES formation, which implementation required the conclusion about fifty contracts. In Yalta the Concept about formation of CES, 
which is an integral part of the signed Agreement about creation of CES, was also approved. The specified agreement was ratified by parliaments of Belarus, Kazakhstan Russia in April, 2004.

In expert community creation of CES met ambiguous reaction. The Ukrainian experts of a number of the analytical centers postulated the thesis about unprofitableness of Ukraine participation in CES as this step contradicts the Constitution of Ukraine and a strategic course of the country to integration into the euro atlantics structures. Thus, Ukraine refused participation in CES.

In June, 2006 the decision is made that further work on formation of the Customs union will take place on the basis of EurAsEC taking into account CES project practices. Organizational structures on CES formation act now on a platform of EurAsEC Secretariat. Expediency of this decision is dictated by that the purposes and tasks of EurAsEC and CES are identical: creation of the common market and common economic space.

On December 19, 2009 by the Decision of the Eurasian economic community of interstate council (the supreme authority of the Customs union) was approved the Plan of action on Common economic space of Republic of Belarus, the Republic of Kazakhstan and the Russian Federation formation (Ministry of Economic Development of the Russian Federation, 2014).

In December, 2009 at the informal summit in Almaty presidents of the Republic of Belarus, the Republic of Kazakhstan and the Russian Federation approved the Plan of action for 2010-2011 years on formation of the Common economic space of three countries. The plan provided working out and signing by January 1, 2012 of the international treaties providing creation of CES.

CES came into force in the territory of three countries since January 1, 2012 on the basis:

1) decisions of the International State Council of EurAsEC:

- of 19. 12. 2009 No. 35 "About the Plan of action on formation of the Common economic space of Republic of Belarus, the Republic of Kazakhstan and the Russian Federation";

- of 5. 07. 2010 No. 49 "About the course of implementation of the Plan of action on formation of the Common economic space of Republic of Belarus, the Republic of Kazakhstan and the Russian Federation".

2) decisions of the Commission of the Customs union:

- of 27. 01. 2010 No. 158 "About the organization of work for formation of the Common economic space of Republic of Belarus, the Republic of Kazakhstan and the Russian Federation for 2010 - 2011 years";

- of 26. 02. 2010 No. 171 "About the organization of work for formation of the Common economic space of Republic of Belarus, the Republic of Kazakhstan and the Russian Federation for 2010 - 2011 years";

- of 25. 03. 2010 No. 203 "About the course of implementation of the Plan of action on formation of the Common economic space of Republic of Belarus, the Republic of Kazakhstan and the Russian Federation";

- of 16. 04. 2010 No. 217 "About the course of implementation of the Plan of action on formation of the Common economic space of Republic of Belarus, the Republic of Kazakhstan and the Russian Federation";

- of 20. 05. 2010 No. 264 "About the course of implementation of the Plan of action on formation of the Common economic space of Republic of Belarus, the Republic of Kazakhstan and the Russian Federation";

- of 18. 06. 2010 No. 291 "About the course of implementation of the Plan of action on formation of the Common economic space of Republic of Belarus, the Republic of Kazakhstan and the Russian Federation";

- of 18. 08. 2010 No. 367 "About the course of implementation of the Plan of action on formation of the Common economic space of Republic of Belarus, the Republic of Kazakhstan and the Russian Federation";

- of 21. 09. 2010 No. 409 "About the course of implementation of the Plan of action on formation of the Common economic space of Republic of Belarus, the Republic of Kazakhstan and the Russian Federation" (Miticheva, 2013).

CES represents one of forms of the interstate integration which purpose is liberalization of the external economic relations within association and implementation of collective protectionism beyond its limits. Problem of CES is providing so-called "four freedoms" between the participating states: movements of goods, the capitals, services and labor, and also providing the beginnings of coordination of economic policy of the participating states concerning macroeconomic and financial sector, transport and power, trade, industrial and agro-industrial complexes and so forth (Kofner, 2013).

CES - the economic zone formed by several states which has united in the economic union. Within this zone high degree of unity and coherence of their economic actions is reached, the uniform currency is used, the 
uniform customs duties are entered, the foundation of uniform economic policy is laid (Shestakov, 2000).

Formation of uniform economic policy is one of the priority directions by which the participating states are guided at Common economic space creation. The purpose of uniform economic policy is the creating favorable conditions for increase of economy's internal stability of CES participating states, harmonization of three Countries legislation, and also integration deepening within the Common economic space. For the countries of the Common economic space participants the principle of realization of "four freedoms" works: free movement of goods, services, capitals and labor. The general direction of integration will be set by a number of agreements which will allow the states, participants of CES to conduct their economic activity on the general legal conditions in the territory of any state of CES participant.

These Agreements are signed by the Parties participants of the Common economic space of 09. 12. 2010: Agreement on the government (municipal) procurements (2010); Agreement on trade of services and investments in member states of the common economic space (2010); Agreement on uniform rules of agriculture state support (20); Agreement on uniform rules of granting industrial subsidies (2010); Agreement on the coordinated macroeconomic policy (2010); Agreement on the competition uniform principles and rules (2010); Agreement on the uniform principles of regulation in the sphere of security and protection of intellectual property rights (2010).

Formation of the common economic space is directed on trust increase to national currencies of the Parties, as in the domestic currency market of each participating state of the Agreement, and in the international currency markets.

The countries of CES create necessary organizational and legal conditions at national and interstate level for development of integration processes in the currency sphere, coordination and endorsement of currency policy: Agreement on the agreed principles of currency policy in the participating states of the Common economic space (2010); Agreement on creation of conditions in the financial markets for ensuring free movement of the capital in the participating states of the Common economic space (2010).

The analysis of international legal documents showed that the concepts "common economic space, "unity of economic space" and "Common Economic Space" in one international treaties are used as equivalent, in others the as isolated and not identical. These terms used in the international practice in the theory of the right are considered not certain, not having accurate legal value.

In turn, different interpretations in understanding of these terms considerably complicate ensuring authenticity of the international treaty provisions, and also practical use of the international treaties system operating with specified concepts at regulation of the international economic relations. This situation is actualized as a result of versatile and multidirectional integration by the Republic of Kazakhstan caused by the conclusion of a large number of international treaties, in which the parties set the tasks of formation uniform or the general (and in some at the same time - uniform and the general) economic space.

Non-execution by the parties of assumed liabilities, today, don't exclude in the future of the conflicts owing to absence of unity of terminology and an available different interpretation of the terms established by different international treaties. This problem now has no extreme relevance as, the majority of international treaties has declarative character, and besides, the majority of the specified contracts isn't realized because has moral and political character, or that their provisions are mutually ignored by the parties, and therefore mutual claims and demands for execution of assumed liabilities aren't made.

It is remarkable that in the national legislation of the Republic of Kazakhstan the concept "common economic space" has no normative definition, steadily and stable opening its legal contents in spite of the fact that it is used for designation of strategic objectives and tasks of the state, the principles of adoption of administrative decisions in tens program and political documents, laws and subordinate regulations.

The available definitions of the common economic space formulated within geographical and geopolitical concepts, the neoclassical and neoinstitutional theories are used in regulations, program and strategic documents in different forms:

- as the territory determined by geographical boundaries in which there are certain economic processes and the phenomena arise, the economic relations exist and stop;

- as the principle of emergence, existence and the termination of the economic relations in the conditions of developed economy;

- as integration association. 
Absence of uniform understanding of the term "common economic space" in national legal systems of the Post-Soviet countries and the general norms explaining that is understood as a common economic space in the interstate relations, led to that the concept "common economic space" is used along with the concept "Common Economic Space", not only in different, but also in one international treaty.

The first international treaty in which the concept "common economic space" receives the definition, is the Contract on the Customs union and the Common economic space of February 26, 1999 where is defined that this space consisting of the parties territories on which the same mechanisms of regulation the economy based on the market principles and application of harmonized rules of law operate, exists uniform infrastructure and is carried out the coordinated tax, monetary and credit, currency and financial, trade and customs policy, providing free movement of goods, services, capital and labor.

In the second international contract containing the definition of the common economic space - the Agreement on formation Uniform economic spaces of September 19, 2003, understand the economic space uniting customs territories of the parties on which mechanisms of regulation of the economies operate, based on the uniform principles providing free movement of goods, services, capital and labor and is carried out uniform foreign trade and coordinated, in that measure and in that volume in what it is necessary for ensuring the equal competition and maintenance of macroeconomic stability, tax, monetary and credit and monetary policy. Thus, definition of the common economic space undergoes a certain transformation.

Coming into effect since January 1, 2012 of 17 international contracts marks the beginning of real functioning of the Common economic space of Kazakhstan, Russia, Belarus - the space consisting of territories of the states on which operate the same mechanisms of the economy regulation based on the market principles and application of harmonized rules of law, there is the uniform infrastructure and the coordinated tax, monetary and credit, currency and financial, trade and customs policy, providing free movement of goods, services, capital and labor is carried out.

Formation of the Common economic space became the next stage of the Eurasian integration upon completion of which is supposed transition to the Eurasian Economic Union (EEU) formation, providing further deepening of cooperation of the participating states in the economic sphere and social and economic problems.

On November 18, 2011 heads of three states adopted "The declaration on the Eurasian economic integration". As appears from the Declaration, by 2015 codification of standard and legal base of the Customs union and the Common economic space has to be complete. It means legislation systematization, high-quality conversion of existing rules, elimination of in coordination, completion of gaps and cancellation of outdated norms. Codification doesn't provide that earlier reached agreements are revised, on the contrary, they take the systematized form, are reduced to the common denominator.

Development and acceptance of CES uniform trade and economic policy's strategy, concepts of uniform industrial and agricultural policy, and also plans of their realization is necessary for the direction of the Eurasian integration process on economic development purposes solution. Further creation of system of the EEU development strategic planning, including long-term forecasts, medium-term concepts and strategies of trade, industrial, agricultural, scientific and technical policy, the main directions of social and economic, monetary and credit and tax policy, and also interstate programs and the plans of measures on their realization is necessary.

Important feature of the Eurasian integration process is its open character. At the same time, there are problem aspects demanding the analysis, judgment and possibility of the fastest decision.

The most difficult problem is the special position of Ukraine on key questions of integration within CES. The present management, as well as illegally overthrown as a result of December events of 2013 old, can't define the most favorable political policy of the country. However, the bias of ruling circles on a course of "the European development" already is now definitely visible. Advantages of euro integration are obvious to Ukraine. Headed course for the forced accession to the European political and economic structures it can be hardly essentially corrected in the next years. Ukraine has today more close connections with the European Union, than with CIS countries and more actively develops with it trade and economic relations. Except the objective factors defining the European choice of Ukraine, a number of strong subjective factors, having ethno psychological character, works also (Nurmaganbet and Nakisheva, 2012).

The similar situation develops in Moldova which along with deterioration and without that deplorable state of the economy will receive in association with EU an inevitable aggravation of the conflict to the Pridnestrovian Republic. Until recently the same political choice imposed to Armenia which from Association with EU along with economic losses would receive weakening of the foreign policy situation. 
One more important problem there is a coordination of positions of the CES countries under the terms of accession to WTO. Negotiations on the introduction are priority for all participating countries of the project. These countries are under pressure in a question of expanded access to the markets, first of all energy resources, an agricultural and industrial output, as conditions of approval of the accession to the organization from other members. The greatest concern is caused also by the position of Ukraine which forces accession to WTO, at the expense of concessions which can have unpredictable consequences. The government of Ukraine plans to become until the end of the current year the member of the WTO. It the USA actively support, EU and other countries. However conditions on which Ukraine can become the member of the WTO, will compel Russia, and it is possible also Belarus to protect the markets by introduction of customs restrictions that respectively impugns an idea of Ukraine about creation within CES of free trade zone without withdrawals and restrictions.

Certainly, any integration process has political motivation as demands the international agreements. However, too strong domination of political reasons over the economic is fraught with serious losses and the conflicts undermining stability of integration formations. To the contrary, political registration of economically mutually advantageous associations gives natural and steady effect of development acceleration and increase of the integrated countries competitiveness.

Unlike the European integration process which consistently conducts to formation of supranational statehood of EU with all attributes and government branches, heads of Russia, Belarus and Kazakhstan accurately outlined borders of the Eurasian integration process by exclusively trade and economic questions. Tasks of the Eurasian integration don't enter neither introduction of the general currency, or formation of supranational parliament, transition to uniform passport and visa regime. In it seems the wisdom of heads of the new independent states which are afraid of integration process politicization. Domination of economic feasibility's motives in it guarantees stability of the formed Eurasian economic union. Within this approach the supranational authority shouldn't apply for an independent political role, its function should limit to coordination of made decisions with the national governments. For this purpose it has to be to the transparent, compact and under control states which have created it.

Taking into account experience the following sequence of actions, along with already accepted and carried-out plans for CES creation, CU development, formation of uniform system of technical regulation can be offered. First, work on reduction of member states' national legislations in full compliance with the CES contract and legal base has to be complete. Secondly, it is necessary to finish elimination of remaining barriers in mutual trade according to the coordinated plans. Thirdly, the extremely actual is improvement of the mechanism and legal ensuring of mutual trade's statistics. Though the methodology of mutual trade's statistics was approved in January, 2011, its quality leaves much to be desired. It is characterized by low reliability and incompleteness of primary information, imperfection of its processing methods, and discrepancy of the data, published by national statistical services. Fourthly, it is necessary to liquidate the gap in the CU contract and legal base in connection with unresolved question of introduction in action of the Agreement on the uniform order of export control of the Customs union member states. Preservation of export control in mutual trade can't be provided owing to lack of customs control. Without unification of national norms of export control their right application and on external border of $\mathrm{CU}$ is complicated. Fifthly, for ensuring effective right application of the legislation of the $\mathrm{CU}$ and CES it is necessary the harmonization of administrative and criminal liability's systems for commission of offenses in the spheres of regulation transferred to supranational level. Sixthly, unification of national legislations standards in the sphere of the public service, defining the status of the officials working in supranational structures is expedient.

After the solution of the listed above questions it is possible transition to formation of the Eurasian economic union. It is especially important the introduction in action of Integral Information System Foreign and Mutual Trade of Custom Union (IISFMTC), providing transparency of all functions of state administration by the Uniform customs territory, including functioning of supranational authority, and also providing reliable statistics of mutual and foreign trade. After that there is possible an entering into the CES contract and legal base the changes providing to supranational authority the right of independent development and initiation of decisions within full powers delegated to the CU and CES (Andrianov, 2006).

\section{Conclusions}

The general definition of CES has to be based on the following elements: free movement of goods, services, financial and labor resources, standardization of the states - the participants' legislation, CES concerning functioning. It doesn't exclude contractual fixing between participants of CES special definition only for the concrete contract. Consequently, such definitions can differ by the form and the list of freely circulating factors of 
production.

CES is the main component of any real regional economic integration. Consequently, standard international legal forms of such integration, effective for any regions, have to be respectively allocated. And specific features of the CES international legal regime in various regions have to correspond each other, except other, developing interregional cooperation.

At change, development of forms of economic integration between the states (economic community, the Customs union, the economic union, etc.) it is expedient to keep stability of the Common economic space which is cornerstone of any of these forms, and, respectively, stability of its international legal bases.

Legal integration within the General European economic space of the European Union - Russia (GEES) shouldn't mean for Russia of full perception by the Russian legislation of the corresponding European standards, on what some European politicians and lawyers focus. Except other, it must be kept in mind that such orientation is able to influence negatively possibility of execution by Russia of its obligations within Common economic space EurAsEC / the Eurasian economic union.

\section{References}

Abdullo, R. G. (2010). Soyuz with Iran and Afghanistan for Dushanbe - the exit from power isolation. Retrieved from http://tjknews.com/?p=2726

Agreement about creation of conditions in the financial markets for ensuring free movement of the capital in the Common economic space participating states. Concluded in Moscow on December 9, 2010. Retrieved from http://www.economy.gov.ru/minec/activity/sections/formuep/capmove/doc20101021_016

Agreement about the agreed principles of currency policy. Concluded in Moscow on December 9, 2010. Retrieved from http://zaki.ru/pagesnew.php?id=65913

Agreement about the coordinated macroeconomic policy. Concluded in Moscow on December 9, 2010. Retrieved from http://bestpravo.ru/federalnoje/ea-instrukcii/w8k.htm

Agreement about the government (municipal) procurements. Concluded in Moscow on December 09, 2010. Retrieved from http://www.consultant.ru/document/cons_doc_LAW_113056/

Agreement about the uniform principles and rules of the competition. Concluded in Moscow on December 9, 2010. Retrieved from http://www.referent.ru/1/176816

Agreement about the uniform principles of regulation in the sphere of security and protection of intellectual property rights. Concluded in Moscow on December 9, 2010. Retrieved from http://www.referent.ru/1/176762

Agreement about trade of services and investments in the states - participants of the Common economic space. Concluded in Moscow on December 09, 2010. Retrieved from http://www.consultant.ru/document/cons_doc_LAW_113098/

Agreement about uniform rules of granting industrial subsidies. Concluded in Moscow on December 9, 2010. Retrieved from http://www.referent.ru/1/176817

Agreement about uniform rules of the state support of agriculture. Concluded in Moscow on December 9, 2010. Retrieved from http://www.zaki.ru/pagesnew.php?id=65906\&

Agreement on Common economic space formation. Concluded on Yalta on September 19, 2003. Retrieved from http://www.lawmix.ru/abrolaw/6180/

Agreement on the Customs union and the Common Economic Space (CES). Concluded in Moscow on February 26, 1999. Retrieved from http://www.consultant.ru/document/cons_doc_LAW_31914/

Andrianov, V. (2006). Problems and prospects of formation of the CIS Common economic space. Retrieved from http://www.nbene.narod.ru/econom/feconom20.htm

Bzhezinsky, Z. (1999). Great chessboard: domination of America and its geostrategic imperatives. International relations. Moscow.

Huasheng, Zh. (2005). China, Central Asia and Shanghai organization of cooperation. Carnegie's Moscow Center. Moscow.

Isingarin, N. K. (1998). Problems of integration into the CIS. Atamura. Almaty.

Koen, A., \& Blank, S. (2011). Russian "sphere of exclusive interests" in Eurasia undermines foreign policy of 
the USA. Retrieved from http://centrasia.ru/newsA.php? st=1311328260.

Kofner Yu. (2013). Common economic space. Retrieved from http:/www.eurasec.com/pozitsija/2688/

Ministry of Economic Development of the Russian Federation. (2014). History of creation of the Common economic space 2014. Retrieved from http://www.ved.gov.ru/vnesheconom/eap/o_eap/

Mirzayev, R. S. (2004). Geopolicy of new Silk way. Institute of actual international problems of the Diplomatic MFA of Russia academy. Moscow.

Miticheva, M. V. (2013). The Euroasian space - ways and mechanisms of expansion of economic integration 2013. Retrieved from http://www.1prime.ru/forum_events/20131017/767522242.html.

Nurmaganbet, E. T., \& Nakisheva, M. K. (2012). Problems and prospects of the CIS the Common economic space formation. Tendencies of development of the modern state and right. Materials of the international correspondence scientific and practical conference. SibAC. Novosibirsk: 101-110.

Olkott, M. (2013). USA and Central Asia. Interest is, but.. falls. Retrieved from http://www.centrasia.ru/newsA.php falls? st=1243395900

Parakhonsky, B. O. (2008). Ukraine in system GUAM. Central Asia and the Caucasus, 3-4(57-58), 119-134.

Shestakov, A. V. (2000). Encyclopedic dictionary of economy and right. Dashkov \& Co. Moscow.

Shumsky, N. N. (2012). Features of organizational and legal system of Commonwealths of Independent States and main directions of its improvement. State and right, 8, 87-91.

Starr, F. (2008). Set of vektors - the unique way for all countries of Central Asia. Retrieved from http://www.centrasia.ru/newsA.php?\%20st=1220302380

Stiglitz, J. E. (2005). Roaring the ninetieth. Disorder seeds. Modern economy and right. Moscow.

\section{Copyrights}

Copyright for this article is retained by the author(s), with first publication rights granted to the journal.

This is an open-access article distributed under the terms and conditions of the Creative Commons Attribution license (http://creativecommons.org/licenses/by/3.0/). 